\title{
Peran DKPP dalam Menegakkan Kode Etik Penyelenggara Pemilu dan Mewujudkan Pilkada Bermartabat
}

\section{The Role of Honorary Council for General Election Executives (DKPP) as Ethical Code Enforcers and Dignified Election of District Heads}

\author{
Mikhael Feka*, Dwityas Witarti Rabawati, Yohanes Arman, Egidius Taemenas \\ Fakultas Hukum Universitas Katolik Widya Mandira, Kupang \\ *E-mail: mikhaelfeka09@gmail.com
}

\begin{abstract}
The Honorary Council for General Election Organizers (DKPP) is an element in the general election execution together with the General Election Commission (KPU) and the General Election Supervision Body (Bawaslu). The main function of the DKPP is to enforce the ethical code for the general election organizers. A dignified general election and election of district heads starts from the general election organizers who are supposed to uphold the general election ethics, although that does not constitute a single factor, in a sense that a dignified general election should be the responsibility of all elements of general election that include the organizers, the pair candidates, political parties, success team, civil servants, national and districts governments, as well as other stakeholders. The problem is that the DKPP's authority is limited to the execution of the general election and does not cover the whole system of the carrying out of the general election and therefore it is difficult to realize a dignified election of district heads, despite the fact that a dignified election will bring about dignified leaders. As a democratic country, Indonesia is supposed to consider not only ethical code for the general election organizers but also ethical code for the whole implementation of the general election.
\end{abstract}

Keywords: DKPP, ethics, dignified general election

\begin{abstract}
Abstraksi
Dewan Kehormatan Penyelenggara Pemilu (DKPP) merupakan unsur penyelenggara pemilu bersama KPU dan Bawaslu. Tugas pokok DKPP adalah menegakkan kode etik penyelenggara pemilu. Pemilu atau pilkada bermartabat dimulai dari penyelenggara pemilu yang menjunjung tinggi etika. Tanpa penyelenggara pemilu yang beretika sangatlah sulit untuk mewujudkan pilkada bermartabat, walaupun hal tersebut bukanlah faktor tunggal, dalam arti bahwa, pilkada bermartabat menjadi tanggung jawab semua elemen baik penyelenggara pemilu, peserta pilkada (pasangan calon), partai politik, tim sukses, Aparatur Sipil Negara (ASN), Pemerintah dan Pemerintah Daerah maupun semua stakeholder lain. Problemnya adalah kewenangan DKPP hanya terbatas pada penyelenggara pemilu dan tidak dapat menjangkau keseluruhan sistem penyelenggaraan pemilu sehingga sulit untuk mewujudkan pilkada bermartabat, padahal pilkada bermartabat akan menghasilkan pemimpin yang bermartabat. Negara Indonesia sebagai negera demokrasi sudah seharusnya memikirkan tidak saja kode etik penyelenggara pemilu tetapi juga kode etik penyelenggaraan pemilu.
\end{abstract}

Kata Kunci: DKPP, Etika, Pilkada Bermartabat 


\section{Pendahuluan}

Dewan Kehormatan Penyelenggara Pemilu (DKPP) merupakan salah satu penyelenggara pemilu yang memiliki tugas mulia yakni menegakkan kode etik penyelengara pemilu. Ketua DKPP RI, Muhammad, menyatakan bahwa hukum dan etika adalah modal utama pilkada serentak tahun 2020. Oleh karenanya rule of law dan rule of ethic harus bersinergi, tidak boleh saling berhadapan tetapi menjadi satu kesatuan. Sebagai perwujudan rule of law Muhammad mengingatkan penyelenggara pemilu yakni KPU dan Bawaslu untuk membuat aturan atau regulasi teknis penyelenggaraan serta pengawasan pilkada serentak dengan tegas, jelas dan terperinci (Majalah Dial Etika, Vol.3, No. 1: 13).

Pilkada serentak 9 Desember 2020 telah usai dilaksanakan. Total daerah yang melaksanakan pemilihan kepala daerah serentak tahun 2020 sebanyak 270 daerah dengan rincian 9 provinsi, 224 kabupaten, dan 37 kota, khusus Provinsi Nusa Tenggara Timur dilaksanakan di 9 kabupaten yakni Kabupaten Timor Tengah Utara, Kabupaten Belu, Kabuaten Malaka, Kabupaten Sumba Barat, Kabupaten Sumba Timur, Kabupaten Ngada, Kabupaten Sabu Raijua, Kabupaten Manggarai dan Kabupaten Manggarai Barat. Pemerintah dan penyelenggara pemilihan menetapkan untuk melanjutkan tahapan penyelenggaraan pemilihan kepala daerah dan wakil kepala daerah yang sempat tertunda karena pandemi covid-19 yang dimulai tanggal 15 Juni 2020 dengan agenda pemutakhiran dan penyusunan daftar pemilih dan puncaknya adalah 9 Desember 2020.

Dasar dilanjutkannya pelaksanaan pilkada serentak 2020 adalah Peraturan Pemerintah Pengganti Undang-Undang Republik Indonesia Nomor 2 Tahun 2020 Tentang Perubahan Ketiga Atas UndangUndang Nomor 1 Tahun 2015 Tentang
Penetapan Peraturan Pemerintah Pengganti Undang-Undang Nomor I Tahun 2014 Tentang Pemilihan Gubernur, Bupati, dan Walikota Menjadi Undang-Undang Pasal 201A Ayat 2 berbunyi "Pemungutan suara serentak yang ditunda sebagaimana dimaksud pada ayat (1) dilaksanakan pada bulan Desember 2020". Pilkada serentak 2020 di tengah pandemi Covid-19 tentunya sebuah pilihan sulit karena di satu sisi harus tetap menjaga pilkada berkualitas dan bermatabat serta pada sisi yang lain harus taat pada protokol covid-19. Antara menjaga pilkada berkualitas 9 Desember 2020 dan menjaga serta menyelamatkan kesehatan masyarakat dari ancaman covid-19 merupakan dua hal yang harus sama-sama dijaga kualitasnya dan prioritas yang harus lebih diutamakan adalah menjaga kesehatan masyarakat karena kalau masyarakat (rakyat) sakit, maka sia-sia pilkada 2020 dan sampai pada selesainya penghitungan suara pada tanggal 9 Desember 2020 tidak ada klaster baru pilkada.

Namun demikian Tahun 2020 tetap menjadi turbulensi bagi penyelenggara pemilu dalam menyelenggarakan pilkada serentak tahap keempat di 270 derah. Goncangan dimulai ketika Word Health Organization (WHO) menetapkan corona virus disease 2019 (covid-19) sebagai pandemi global (11 Maret 2020), menyusul Keputusan Presiden Nomor 12 Tahun 2020 tentang penetapan covid-19 sebagai bencana nasional (13 April 2020). Pilkada yang berintegritas akan menghasilkan pemimpin yang berintegritas, pilkada yang berintegritas diawali dari penyelenggara pemilu yang berintegritas. Di sinilah letak/fondasi dari pilkada bermartabat. Pilkada bermartabat menjunjung tinggi hukum dan etika. Oleh karena itu, pentingnya sinergitas penegakan hukum (law enforcement) dan penegakan kode etik (ethical enforcement). Hukum dan etika tidak boleh dipertentangkan. Hukum dan 
etika itu adalah sebuah dualitas bukan dualisme dan juga bukan versus, dia adalah "dan" bukan hukum atau etika. Karena itu, penyelenggara pemilu dituntut untuk mengelola tugasnya dengan menggunakan hukum dan etika (bdk pengantar Ketua DKPP pada Lapkin DKPP 2020). Kunci dari pilkada bermartabat adalah menjunjung tinggi hukum dan etika penyelenggara pemilu.

Dalam praktik penegakan hukum, etik dan hukum seolah dipisahkan dan menempatkan hukum di atas etika (atau sebaliknya etika di bawah hukum), padahal keduanya bisa saling menghargai dan tidak saling mengeliminir. Memang terkait dengan hukum dan moral (etika) ada perdebatan atau perbedaan antara Weber dan Habermas. Weber berpendapat bahwa hukum adalah satu-satunya alat integrasi sosial di dalam masyarakat. Hukum tidak perlu mendapat legitimasi dari mana-mana tetapi dari dirinya sendiri. Hukum mempunyai rasionalitasnya sendiri dan tidak lagi bergantung pada pandangan moral (Rengka, 2015: 49). Pendapat Weber tersebut mengundang reaksi Habermas. Habermas berpendapat bahwa rasionalitas hukum Weber tidaklah menyebabkan hukum dan moralitas itu harus terpisah satu sama lain. Habermas dengan tegas mengatakan bahwa antara hukum dan moralitas itu ada hubungan yang erat satu sama lain. Habermas memberi argumen bahwa rasionalitas formal hukum seperti yang diuraikan Weber tidak dapat dilihat sebagai rasional dalam artian netral secara moral, karena itu, legitimasi hukum tidak bisa lepas dari pertimbangan moral (Ibid).

Berdasarkan Laporan Kinerja Dewan Kehormatan Penyelenggara Pemilu (DKPP) tahun 2020 tercatat 415 dugaan pelanggaran kode etik penyelenggara pemilu yang dilaporkan ke DKPP RI. Bahwa penetapan bencana non-alam Pandemi Covid-19 di Indonesia pada bulan Maret 2020 tidak menyurutkan angka pengaduan yang masuk ke DKPP. Berdasarkan rekapitulasi data pengaduan diketahui jumlah pengaduan dan/atau laporan yang masuk ke DKPP tahun 2020 sebanyak 415. Jika dibandingkan jumlah pengaduan di tiap bulan, terjadi peningkatan jumlah pengaduan di 4 (empat) bulan terakhir dengan puncak pengaduan terjadi pada bulan November 2020 sebanyak 81 pengaduan disusul 71 pengaduan di bulan Okrober dan 65 pengaduan di bulan September, sedangkan jumlah pengaduan terendah terjadi di bulan Mei 2020. Kenaikan jumlah pengaduan pada bulan September s/d November 2020 sejalan dengan tahapan Pilkada Serentak Tahun 2020 yang memasuki tahapan puncak yakni pasca tahapan pencalonan, tahapan kampanye dan menjelang tahapan pemungutan dan penghitungan suara pada 9 Desember 2020. 
Tabel 1

Pengaduaan Dugaan Pelanggaran Kode Etik Penyelenggara Pemilu Tahun 2020

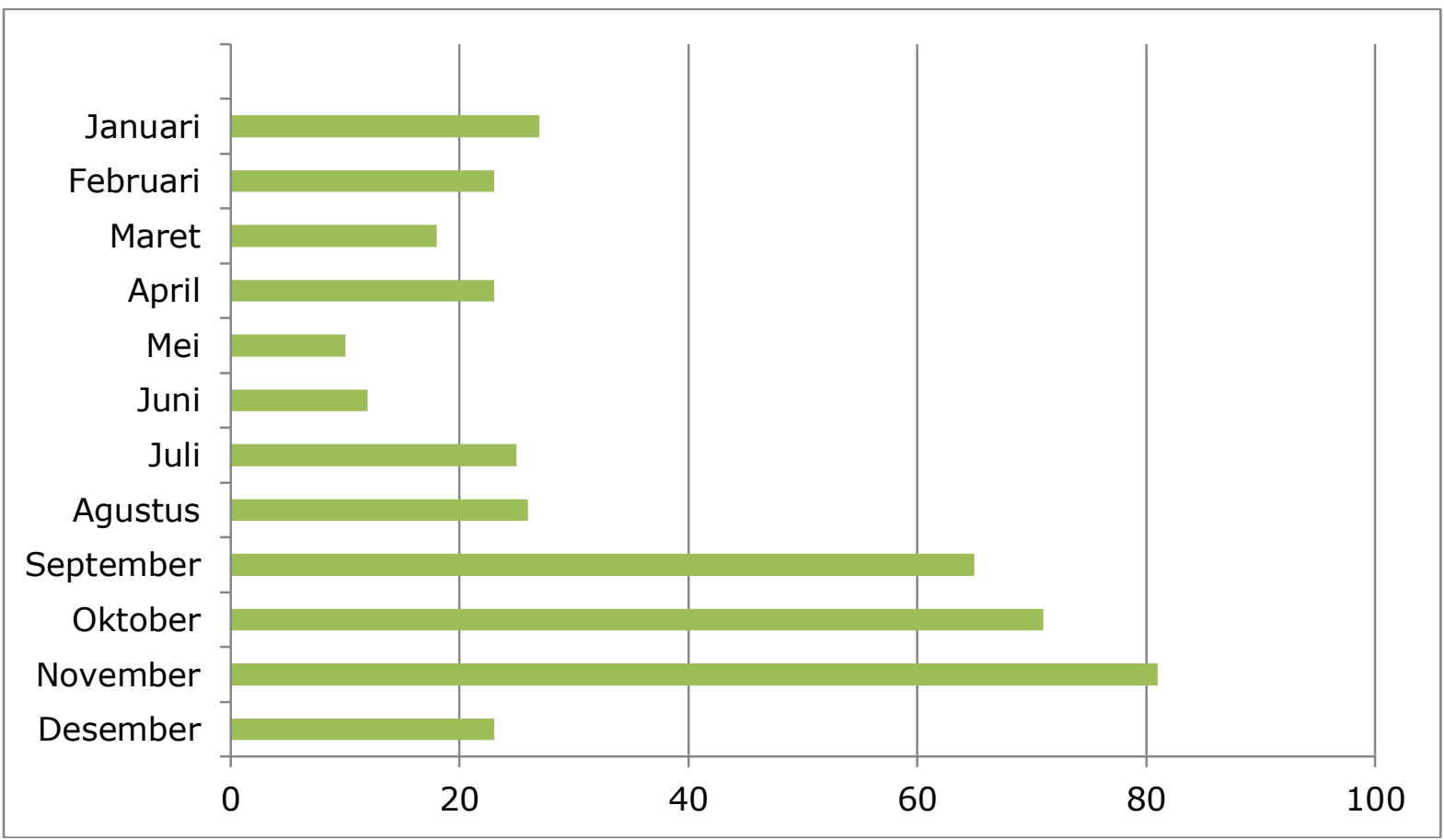

(Sumber: Data Lapkin DKPP Tahun 2020 hlm. 29)

Dari data dugaan pelanggaran kode etik tersebut di atas menunjukkan bahwa ada masalah terkait kode etik yang dilakukan oleh penyelenggara pemilu. Pemilu atau pilkada berkualitas dan bermartabat dimulai dari penyelenggara pemilu yang bermartabat dan berintegritas. Persoalan di atas merupakan persoalan bangsa yang membutuhkan atensi khusus dari semua pihak agar menjaga marwah demokrasi yang dikonkretkan melalui pemilu atau pilkada. Masalah etik merupakan problem utama dalam menciptakan pilkada yang bermartabat. Pilkada yang bermartabat akan menghasilkan pemimpin yang bermartabat. Pilkada bermartabat harus dijalankan oleh penyelenggara pemilu yang bermartabat, namun tidak semata-mata menjadi tanggung jawab penyelenggara pemilu dalam hal ini KPU dan Bawaslu beserta jajarannya masing-masing.

\section{DKPP sebagai Penopang Pilkada Bermartabat}

Dalam UU Nomor 7 Tahun 2017 tentang Pemilihan Umum Pasal 1 angka 7 merumuskan bahwa penyelenggarapPemilu adalah lembaga yang menyelenggarakan pemilu yang terdiri atas Komisi Pemilihan Umum, Badan Pengawas Pemilu, dan Dewan Kehormatan Penyelenggara Pemilu sebagai satu kesatuan fungsi menyelenggarakan pemilu. Rumusan pasal ini menempatkan DKPP sebagai penyelenggara pemilu yang bertugas menegakkan kode etik penyelenggara pemilu (vide Pasal 1 angka 24). DKPP secara khusus diatur dalam Bab III UU Nomor 7 Tahun 2017, dalam Pasal 155 diatur bahwa Ayat (1) DKPP bersifat tetap dan berkedudukan di ibu kota negara. (2) DKPP dibentuk untuk memeriksa dan memutus aduan dan/atau laporan adanya 
dugaan pelanggaran kode etik yang dilakukan oleh anggota KPU, anggota KPU provinsi, anggota, KPU Kabupaten/Kota, anggota Bawaslu, anggota Bawaslu Provinsi dan anggota Bawaslu Kabupaten/Kota. Dalam Pasal 1 Ayat 4 Peraturan DKPP Nomor 2 Tahun 2019 tentang Perubahan Atas Peraturan DKPP Nomor 3 Tahun 2017 tentang Pedoman Beracara Kode Etik Penyelenggara Pemilu merumuskan bahwa Kode Etik Penyelenggara Pemilu adalah suatu kesatuan asas moral, etika, dan filosofi yang menjadi pedoman perilaku bagi penyelenggara pemilu berupa kewajiban atau larangan, tindakan dan/atau ucapan yang patut atau tidak patut dilakukan oleh penyelenggara pemilu.

Sedangkan dalam Pasal 4 Peraturan Bersama Komisi Pemilihan Umum, Badan Pengawas Pemilihan Umum, dan Dewan Kehormatan Penyelenggara Pemilihan Umum Nomor 13 Tahun 2012, Nomor 11 Tahun 2012, Nomor 1 Tahun 2012 Tentang Kode Etik Penyelenggara Pemilihan Umum merumuskan adanya tujuan dari kode etik penyelenggara pemilu adalah untuk menjaga kemandirian, integritas, dan kredibilitas. Pemimpin yang berkualitas dihasilkan dari proses demokrasi yang berkualitas pula. Hal ini tentunya harus dimulai dari penyelenggara pemilu. Kemandirian dapat diartikan bahwa penyelenggara pemilu dalam melaksanakan tahapan pemilu dilakukan secara bebas, tanpa intervensi dari siapa dan apa pun, berdiri di atas kaki sendiri. Kemandirian ini didasarkan pada hukum, etika dan moral. Integritas dapat dimaknai bahwa penyelenggara pemilu memiliki konsistensi pemikiran dan tindakan yang berdasarkan pada sumpah/janji jabatan, nilai-nilai dan norma-norma hukum yang berkaitan dengan tugas pokok dan fungsi sebagai penyelenggara pemilu serta memiliki pribadi yang jujur dan karakter yang kuat serta kebijaksanaan, sedangkan kredibilitas dapat dimaknai bahwa penyelenggara pemilu harus memiliki dan memperjuangkan kualitas, komitmen, kapabilitas, atau bahkan kekuatan yang digunakan untuk menimbulkan rasa kepercayaan diri yang pada akhirnya berpengaruh pada kepercayaan publik kepada penyelenggara pemilu.

Untuk menjaga ketiga nilai tersebut, yakni kemandirian, integritas dan kredibilitas, maka penyelenggara pemilu harus berpegang teguh pada landasan dan prinsip dasar etika dan perilaku penyelenggara pemilu.

DKPP selaku lembaga yang diamanatkan undang-undang untuk menegakkan kode etik penyelenggara pemilu diselenggarakan dengan prinsip cepat, terbuka, dan sederhana.

Pasal 2 Ayat 1 Peraturan Dewan Kehormatan Penyelenggara Pemilihan Umum Republik Indonesia Nomor 3 Tahun 2017 Tentang Pedoman Beracara Kode Etik Penyelenggara Pemilihan Umum mengatur bahwa dugaan pelanggaran kode etik dapat diajukan kepada DKPP berupa:

a. Pengaduan dan/atau Laporan; dan/atau

b. Rekomendasi DPR.

Sedangkan Pasal 4 Ayat 1 dan 2 Pengaduan dan/atau Laporan (Pengadu/Pelapor) diajukan oleh:

a. Penyelenggara Pemilu;

b. Peserta Pemilu;

c. Tim kampanye;

d. Masyarakat; dan/atau

e. Pemilih.

Sedangkan, yang menjadi teradu dan/atau terlapor adalah anggota KPU, anggota KPU Provinsi, KIP Aceh, anggota KPU Kabupaten/Kota, KIP Kabupaten/Kota, anggota PPK, anggota PPS, anggota PPLN, anggota KPPS, anggota KPPSLN, anggota Bawaslu, anggota Bawaslu Provinsi, anggota Bawaslu Kabupaten/Kota, anggota Panwaslu Kecamatan, anggota Panwaslu Kelurahan/Desa, anggota Pengawas Pemilu 
Luar Negeri, dan/atau Pengawas TPS serta jajaran kesekretariatan penyelenggara pemilu yang diduga melakukan pelanggaran Kode Etik Penyelenggara Pemilu (Pasal 1 Ayat 30 Peraturan DKPP Nomor 2 Tahun 2019). Selain pengadu dan teradu, ada juga yang namanya pihak terkait yakni pihak yang terkait dengan penyelenggaraan pemilu. Secara garis besar tahapan proses pemeriksaan kode etik penyelenggara pemilu dibagi menjadi tiga bagian yakni:

1. Verifikasi administrasi adalah pemeriksaan formil dalam rangka pemeriksaan kelengkapan persyaratan pengaduan dan/atau laporan.

2. Verifikasi material adalah pemeriksaan terhadap alat bukti dan relevansinya terhadap pokok pengaduan yang mengarah pada dugaan pelanggaran kode etik.

3. Persidangan adalah sidang yang dilakukan oleh DKPP/Tim Pemeriksa Daerah untuk memeriksa dan mengadili dugaan pelanggaran kode etik penyelenggara pemilu.

Mengenai tahapan persidangan sebagaimana disebutkan di atas, dapat dilakukan secara langsung maupun tidak langsung. Secara langsung dapat dilaksanakan sidang di DKPP atau sidang di daerah setempat. Sedangkan tidak langsung dapat dilakukan melalui video conference (Materi Dewan Kehormatan Penyelenggara Pemilu pada Acara Rapat Dengar Pendapat dengan Komisi II DPR-RI: 2020).

DKPP memiliki tugas, wewenang dan kewajiban dalam menyelenggarakan penegakan kode etik penyelenggara pemilu. Tugas DKPP diatur dalam Pasal 159 Ayat (1) UU Nomor 7 Tahun 2017 tentang pemilu, meliputi:

a. menerima aduan dan/atau laporan dugaan adanya pelanggaran kode etik yang dilakukan oleh penyelenggara pemilu; dan

b. melakukan penyelidikan dan verifikasi, serta pemeriksaan atas aduan dan/atau laporan dugaan adanya pelanggaran kode etik yang dilakukan oleh penyelenggara pemilu.

Selanjutnya Pasal 159 Ayat (2) UU Nomor 7 Tahun 2017 tentang pemilu mengatur wewenang DKPP, meliputi:

a. memanggil penyelenggara pemilu yang diduga melakukan pelanggaran kode etik untuk memberikan penjelasan dan pembelaan;

b. memanggil pelapor, saksi, dan/atau pihak lain yang terkait untuk diminta keterangan, termasuk dokumen atau bukti lain;

c. memberikan sanksi kepada penyelenggara pemilu yang terbukti melanggar kode etik; dan

d. memutus pelanggaran kode etik.

Adapun kewajiban DKPP diatur dalam Pasal 159 Ayat (3) UU Nomor 7 Tahun 2017 tentang pemilu yakni:

a. menerapkan prinsip menjaga keadilan, kemandirian, imparsialitas, dan transparansi;

b. menegakkan kaidah atau norma etika yang berlaku bagi penyelenggara pemilu;

c. bersikap netral, pasif, dan tidak memanfaatkan kasus yang timbul untuk popularitas pribadi; dan

d. menyampaikan putusan kepada pihak terkait untuk ditindaklanjuti.

Selanjutnya dalam Pasal 162 UU Nomor 7 Tahun 2017 tentang pemilu ditegaskan bahwa untuk mendukung kelancaran tugas dan wewenang DKPP, dibentuk sekretariat DKPP. Perihal pembentukan sekretariat DKPP beserta tugas, fungsi dan wewenang sekretariat 
DKPP diatur dalam Peraturan Presiden Nomor 67 Tahun 2018 (Laporan Kinerja Dewan Kehormatan Penyelenggara Pemilu 2019: 16).

Untuk mendukung dan memperkuat DKPP mengingat kedudukan DKPP hanya berada di ibu kota negara, maka sesuai dengan ketentuan Pasal 164 UU Nomor 7 Tahun 2017 tentang Pemilu, DKPP dapat membentuk Tim Pemeriksa Daerah (TPD) di setiap provinsi yang bersifat ad hoc yang berjumlah 4 (empat) orang dan mengenai ketentuan mengenai tugas, fungsi, wewenang, dan tata kerja tim pemeriksa daerah diatur dengan Peraturan DKPP.

Kewenangan TPD diatur dalam Pasal 6 Peraturan DKPP Nomor 5 Tahun 2017 sebagaimana diubah dengan peraturan DKPP Nomor 1 Tahun 2019 yang pada pokoknya memiliki kewenangan untuk memeriksa jajaran KPU Provinsi atau KIP Provinsi Aceh, KPU Kabupaten/kota atau KIP Kabupaten/kota, Bawaslu Provinsi atau Panwaslih Provinsi Aceh, Bawaslu Kabupaten/kota atau panwaslu Kabupaten/kota, dan pelanggaran kode etik jajaran ad hoc yang dilakukan bersama-sama dengan jajaran tingkat Kabupaten/Kota dan/atau Provinsi.

Selanjutnya, berdasarkan Pasal 6 ayat (2) peraturan a quo dalam menjalankan kewenangannya, TPD dapat:

a. Menghadirkan para pihak, saksi, ahli, dan pihak terkait;

b. Mengambil sumpah saksi dan/atau ahli yang memberikan keterangan dan/atau pendapat dalam sidang persidangan;

c. Meminta keterangan dalam pihak, saksi, dan pihak terkait dan/atau pendapat ahli;

d. Memeriksa dan mengesahkan alat bukti dan bahan bukti yang disampaikan dalam sidang pemeriksaan;dan

e. Meminta alat bukti dan barang ukti tambahan lainnya.

Adapun kewajiban TPD sebagaimana diatur dalam Pasal 7 peraturan a quo ialah sebagai berikut:

a. Melaksanakan keputusan DKPP untuk memeriksa dugaan pelanggaran kode etik;

b. Melaksanakan proses pemeriksaan dengan prinsip cepat, terbuka, dan sederhana;

c. Mendengarkan semua pihak yang berkepentingan dengan perkara yang ditandatangani dan dipertimbangkan semua alasan yang diajukan secara adil;

d. Tidak mengeluarkan pendapat atau pernyataan yang terkait dalam perkara;

e. Menjaga rahasia yang dipercayakan kepadanya, termasuk hasil rapat sepanjang tidak bertentangan dalam peraturan perundang-undangan;dan

f. Melaksanakan tugas, wewenang, dan kewajiban berdasarkan perundangundangan serta kode etik dan pedoman perilaku Dewan Kehormatan Penyelenggara Pemilu.

\section{Penanganan Kode Etik Penyelenggara Pemilu}

Penetapan bencana non-alam pandemi covid-19 di Indonesia pada bulan Maret 2020 tidak menyurutkan angka pengaduan yang masuk ke DKPP. Berikut ini ditampilkan rekapitulasi data pengaduan sebagai berikut: 
Tabel 2

Rekapitulasi Pengaduan Berdasarkan Penyampaian

\begin{tabular}{|l|c|}
\hline \multicolumn{1}{|c|}{ Jenis Pengaduan } & Total \\
\hline Tidak Langsung (melalui surat (pos atau email)) & 319 \\
\hline Pengaduan Langsung & 96 \\
\hline Total & $\mathbf{4 1 5}$ \\
\hline
\end{tabular}

(Sumber: Data Lapkin DKPP Tahun 2020 hlm. 30)

Tabel 3

Pengaduan Berdasarkan Tahapan Pilkada Serentak 2020

\begin{tabular}{|l|c|}
\hline \multicolumn{1}{|c|}{ Tahapan Pilkada 2020 } & Jumlah \\
\hline Pemenuhan Persyaratan Dukungan Bakal Pasangan Calon Perseorangan & 36 \\
\hline Penetapan Pasangan Calon & 29 \\
\hline Pembentukan Panwascam dan PPL & 24 \\
\hline Pembentukan PPK dan PPS & 19 \\
\hline Pelaksanaan Kampanye & 20 \\
\hline Verifikasi Persyaratan Pencalonan dan Syarat Bakal Pasangan Calon & 16 \\
\hline Pendaftaran Bakal Pasangan Calon & 17 \\
\hline Pemutakhiran dan Penyusunan Daftar Pemilih & 3 \\
\hline Total & $\mathbf{1 6 4}$ \\
\hline
\end{tabular}

(Sumber: Data Lapkin DKPP Tahun 2020 hlm. 32)

Tabel 4

Pengaduan berdasarkan Unsur Pengadu Tahun 2020

\begin{tabular}{|l|c|}
\hline Unsur Pengadu & Jumlah \\
\hline Masyarakat/Pemilih & 229 \\
\hline Peserta Pemilu/Bapaslon & 127 \\
\hline Penyelenggara Pemilu & 59 \\
\hline Total & $\mathbf{4 1 5}$ \\
\hline
\end{tabular}

(Sumber: Data Lapkin DKPP Tahun 2020 hlm. 34) 
Tabel 5

Pengaduan Berdasarkan Unsur Teradu

\begin{tabular}{|l|c|}
\hline \multicolumn{1}{|c|}{ Lembaga } & Jumlah \\
\hline KPU Kab/Kota & 568 \\
\hline Bawaslu Kab/Kota & 447 \\
\hline KPU Provinsi & 101 \\
\hline KPU RI & 65 \\
\hline Bawaslu Provinsi & 50 \\
\hline Sekretariat KPU & 23 \\
\hline Panwascam & 22 \\
\hline PPK/PPD & 23 \\
\hline PPS & 18 \\
\hline Sekretariat Bawaslu & 18 \\
\hline Lain-lain & 14 \\
\hline PPL & 1 \\
\hline Bawaslu RI & 1 \\
\hline KPPS & 0 \\
\hline Total & $\mathbf{1 3 5 1}$ \\
\hline
\end{tabular}

(Sumber: Data Lapkin DKPP Tahun 2020 hlm. 35)

Tabel 6

Putusan DKPP Berdasarkan Jenis Pemilu Tahun 2020

\begin{tabular}{|c|c|c|c|c|c|}
\hline No. & Jenis Pemilu & $\begin{array}{c}\text { Perkara } \\
\text { Diputus }\end{array}$ & $\begin{array}{c}\text { Persentase } \\
\text { Perkara }\end{array}$ & $\begin{array}{c}\text { Jumlah } \\
\text { Teradu }\end{array}$ & $\begin{array}{c}\text { Persentase } \\
\text { Teradu }\end{array}$ \\
\hline 1. & Pemilu & 77 & $46,6 \%$ & 389 & $55,7 \%$ \\
\hline 2. & Pilkada & 36 & $21,8 \%$ & 195 & $28,0 \%$ \\
\hline 3. & Non-Tahapan & 52 & $31,6 \%$ & 114 & $16,3 \%$ \\
\hline \multicolumn{2}{|r|}{ Total } & $\mathbf{1 6 5}$ & $\mathbf{1 0 0 \%}$ & $\mathbf{6 9 8}$ & $\mathbf{1 0 0 \%}$ \\
\hline
\end{tabular}

(Sumber: Data Lapkin DKPP Tahun 2020 hlm. 44)

Dari data-data tersebut di atas menunjukkan bahwa masalah etik penyelenggara masih menjadi masalah serius dalam pelaksanaan pilkada di Indonesia. Etika merupakan hal penting untuk menciptakan pilkada bermartabat. Namun untuk menciptakan pilkada bermartabat tidak hanya semata-mata menjadi tanggung jawab penyelenggara pemilu tetapi menjadi tanggung jawab partai politik, peserta, tim sukses, pemantau pemilu, masyarakat dan semua elemen masyarakat.

Etika dan Urgensi Demokrasi Pilkada 2020

Etika merupakan salah satu cabang dari ilmu filsafat yang membahas mengenai 
konsep perilaku manusia. Maka, pembahasan tentang etika pun sering kali dikenal dengan istilah baik dan buruk. Sebagai cabang filsafat yang mempelajari tentang perilaku manusia, etika dari sudut pandang peristilahan terdapat banyak istilah antara lain misalnya, moral, norma dan etiket (Muhammad, 2019: 3).

Istilah etika berasal dari bahasa Yunani kuno. Bentuk tunggal kata 'etika' yaitu ethos, sedangkan bentuk jamaknya yaitu ta etha. Ethos mempunyai banyak arti yaitu tempat tinggal yang biasa, padang rumput, kandang, kebiasaan/adat, akhlak, watak, perasaan, sikap, cara berpikir. Sedangkan arti ta etha, yaitu adat kebiasaan. Jadi, etika adalah suatu ilmu yang membahas perbuatan baik dan buruk manusia sejauh yang dapat dipahami oleh pikiran manusia. Dan etika profesi terdapat suatu kesadaran yang kuat untuk mengindahkan etika profesi pada saat mereka ingin memberikan jasa keahlian profesi kepada masyarakat yang memerlukan. Aristoteles membagi pengertian etika menjadi dua, yaitu terminius technikus dan manner and custom. terminius technikus merupaka etika yang dipelajari sebagai ilmu pengetahuan yang mempelajari suatu problema tindakan atau perbuatan manusia. Manner dan custom merupakan suatu pembahasan etika yang berhubungan atau berkaitan dengan tata cara dan adat kebiasaan yang melekat dalan kodrat manusia atau in herent in human nature yang sangat terkait dengan arti baik dan buruk suatu perilaku, tingkah laku atau perbuatan manusia (https://www.dosenpendidikan.co.id/etika).

Menurut JJ.H. Bruggink, etika adalah teori tentang moral dalam arti keseluruhan kaidah dan nilai. Jika berbicara mengenai teori tentang moral maka akan menggunakan istilah etika (JJ.H. Bruggink, 2011: 225). Lebih lanjut R. Van Haersolte dalam bukunya yang berjudul Kleine Wijsgerige
Ethiek sebagaimana dikutip oleh JJ.H. Bruggink menyatakan bahwa perkataan etika kadang-kadang digunakan sebagai sinonim moral. Di sampingnya masih terdapat penggunaan yang lain. Kenyataan bahwa pengetahuan tentang (bahasa) Yunani berabad-abad kurang luas ketimbang tentang bahasa Latin, maka perkataan etika telah dibuat menjadi perkataan khas para cendekiawan, yang sering dipergunakan untuk menunjuk pada refleksi intelektual terhadap moral (Ibid). Moral dan etika memiliki suatu penilaian yang sama tentang baik atau buruk, pantas atau tidak pantas.

Menurut Sonny Keraf, kode etik merupakan kaidah moral yang berlaku khusus untuk orang-orang profesional di bidang tersebut, sedangkan menurut $\mathrm{R}$. Soebekti, dalam tulisannya yang berjudul "Etika Bantuan Hukum", kode etik suatu profesi berupa norma-norma yang harus diindahkan oleh orang-orang yang menjalankan tugas profesi tersebut (https://www.dosenpendidikan.co.id/kodeetik).

Menurut Kamus Besar Bahasa Indonesia, etika yaitu ilmu tentang baik dan buruknya perilaku, hak dan kewajiban moral, sekumpulan asa atau nila-nilai yang berkaitan dengan akhlak, nilai mengenai benar atau salahnya perbuatan atau perilaku yang dianut masyarakat.

Pilkada 2020 merupakan perwujudan dari kedaulatan rakyat. Makna dari kedaulatan berada di tangan rakyat, yaitu bahwa rakyat memiliki kedaulatan, tanggung jawab, hak dan kewajiban untuk secara demokratis memilih pemimpin yang akan membentuk pemerintahan guna mengurus dan melayani seluruh lapisan masyarakat, serta memilih wakil rakyat untuk mengawasi jalannya pemerintahan (Teguh Prasetyo dan Muhammad, 2019: 129). Pelaksanaan kedaulatan rakyat dalam bentuk pilkada tidak sekedar untuk memilih kepala daerah dan wakil kepala daerah atau dimaknai 
secara sempit, yakni pengertian secara etimologi, tetapi lebih mengedepankan bahwa pilkada itu untuk membangun kesadaran dan partisipasi semua pihak sebagai makhluk mulia yang bermartabat untuk mengonstruksi sistem demokrasi yang mana antara pemimpin dan rakyatnya mempunyai hubungan batin yang sama dalam membangun keadilan dan kesejahteraan.

Teguh Prasetyo menggagas dan memelopori lahirnya teori keadilan bermartabat. Keadilan bermartabat sebagai suatu grand theory hukum memandang pancasila sebagai postulat dasar tertinggi, yaitu sumber dari segala inspirasi yuridis untuk menjadikan etika politik (demokrasi) khususnya etika kelembagaan penyelenggaraan pemilu sebagai manifestasi paling konkret dari demokrasi yang dapat menciptakan masyarakat bermartabat. Dengan begitu, hukum dapat memanusiakan manusia (Teguh Prasetyo, 2019: 25). Manusia menjadi tuan atas hukum bukan sebaliknya sehingga hukum diarahkan sepenuhnya untuk melayani manusia sebagai tuannya. Manusia menjadi fokus dan pelaku hukum itu sendiri untuk mencapai keadilan dan kesejahteraan bersama. Dalam konteks pilkada, untuk mengonstruksi pilkada yang bermartabat, kualitas manusia sebagai penyelenggara pemilu diuji kemampuan dan kelayakannya sebagai tuan atas hukum untuk meletakkan pilkada (demokrasi) di atas segala-galanya, apalagi di tengah pandemi covid-19 yang memiliki banyak keterbatasan ini.

Pemikiran Teguh Prasetyo tentang hukum harus memanusiakan manusia dan seyogyanya menjunjung tinggi nilai-nilai kemanusiaan menurut hakikat dan tujuan hidupnya (Ibid) karena manusia adalah makhluk yang mulia sebagai ciptaan Tuhan Yang Maha Esa sebagaimana termaktub dalam sila ke-2 pancasila, yakni kemanusiaan yang adil dan beradab. Di dalam sila itu, terkandung nilai pengakuan terhadap harkat dan martabat manusia dengan segala hak dan kewajibannya serta manusia juga mendapatkan perlakuan yang adil dari manusia lainnya dan mendapatkan hal yang sama terhadap diri sendiri, alam sekitar dan terhadap Tuhan (Ibid). Manusia ditempatkan pada tempat yang mulia sudah sejak lama ditulis oleh Pico Della Mirandola pada awal zaman modern dalam karangannya yang berjudul "De Hominis Dignitate" mengemukakan bahwa tidak ada di dunia ini yang lebih menakjubkan (mirum) daripada manusia. Mengapa manusia paling hebat di dunia? Sebab manusia tinggal di luar tangga makhluk alam. Ia dapat mengambil tempat yang dikehendakinya. Kehebatan ini diterimanya dari Tuhan (Huijbers, 1995: 99). Pemikiran cemerlang dari Pico ini mendapat dukungan dari Imanuel Kant yang mengemukakan bahwa nilai manusia terletak dalam kebebasannya dan otonominya, yang nyata dalam praksis hidup, dalam hidup moralnya. Tetapi hidup moral yang bernilai itu berakar dalam nilai religiusnya, sebab kebebasannya berasal dari Tuhan (Ibid).

Pemerintah, DPR dan penyelenggara pemilu menetapkan untuk melanjutkan tahapan penyelenggaraan pemilihan kepala daerah dan wakil kepala daerah yang sempat tertunda karena pandemi covid-19. Lanjutan tahapan pemilihan gubernur dan wakil gubernur, bupati dan wakil bupati serta walikota dan wakil walikota dimulai tanggal 15 Juni 2020 dengan agenda pemutakhiran dan penyusunan daftar pemilih dan puncaknya adalah 9 Desember 2020. Dasar dilanjutkannya pelaksanaan pilkada serentak 2020 adalah Peraturan Pemerintah Pengganti Undang-Undang Republik Indonesia Nomor 2 Tahun 2020 tentang Perubahan Ketiga Atas Undang-Undang Nomor 1 Tahun 2015 tentang Penetapan Peraturan Pemerintah Pengganti Undang-Undang Nomor I Tahun 2014 Tentang Pemilihan Gubernur, Bupati, 
dan Walikota menjadi Undang-Undang Pasal 201A Ayat 2 berbunyi "Pemungutan suara serentak yang ditunda sebagaimana dimaksud pada ayat (1) dilaksanakan pada bulan Desember 2020”.

Pilkada serentak 2020 di tengan Pandemi Covid-19 tentunya sebuah pilihan sulit karena di satu sisi harus tetap menjaga pilkada berkualitas dan pada sisi yang lain harus taat pada protokol covid-19. Antara menjaga pilkada berkualitas 9 Desember 2020 dan menyelamatkan kesehatan masyarakat dari ancaman covid-19 merupakan dua hal yang harus sama-sama dijaga kualitasnya. Prioritas yang harus lebih diutamakan adalah menjaga kesehatan masyarakat karena kalau masyarakat (rakyat) sakit, sia-sialah pilkada 2020. Dengan demikian, pemerintah dan penyelenggara pemilu perlu menaruh atensi serius dalam menyelenggarakan pilkada di tengah pandemi covid-19 (Feka, 2020).

Untuk menjaga pilkada berkualitas di tengah pandemi covid-19, setidak-tidaknya ditentukan oleh enam faktor berikut: regulasi, anggaran, penyelenggara pemilihan, peserta pemilihan, masyarakat dan gugus tugas. Faktor-faktor tersebut sangat menentukan dan saling memengaruhi satu dengan yang lain dalam menentukan kualitas pilkada dan masyarakat tetap bebas dari ancaman covid-19. Pertama, faktor regulasi. Faktor ini sangat menentukan karena terkait dengan payung hukum dilaksanakannya pilkada di tengah pandemi covid-19 tersebut. UU Nomor 6 Tahun 2020 Penetapan Peraturan Pemerintah Pengganti Undang-Undang Nomor 2 Tahun 2020 tentang Perubahan Ketiga Atas UndangUndang Nomor 1 Tahun 2015 tentang Penetapan Peraturan Pemerintah Pengganti Undang-Undang Nomor 1 Tahun 2014 tentang Pemilihan Gubernur, Bupati, dan Walikota sebagai dasar untuk melaksanakan pilkada 9 Desember 2020 tidak cukup untuk menjawab kebutuhan kualitas pilkada di tengah pandemi covid-19 tersebut sehingga perlu peraturan teknis berupa PKPU dan Perbawaslu untuk memadukan pilkada berkualitas sekaligus menjaga kualitas kesehatan masyarakat. Walaupun UU Nomor 6 Tahun 2020 Penetapan Peraturan Pemerintah Pengganti Undang-Undang Nomor 2 Tahun 2020 tentang Perubahan Ketiga Atas Undang-Undang Nomor 1 Tahun 2015 tentang Penetapan Peraturan Pemerintah Pengganti Undang-Undang Nomor 1 Tahun 2014 tentang Pemilihan Gubernur, Bupati, dan Walikota tidak begitu memadai untuk menjaga kedua hal tersebut, setidak-tidaknya UU Nomor 6 Tahun 2020 ini merupakan jawaban atas kepastian hukum di tengah krisis dan kemendesakan pilkada 2020, apalagi siapa pun tidak bisa memastikan kapan akan berakhir pandemi covid-19 ini.

Kedua, anggaran. Pilkada langsung sudah pasti menelan anggaran yang tidak sedikit apalagi ditambah dengan pandemi, sehingga pemerintah perlu menetapkan anggaran yang cukup bagi penyelenggara, yakni KPU, Bawaslu dan DKPP serta ada satu pihak yang bukan penyelanggara namun sangat menentukkan dalam pilkada 2020 ini adalah gugus tugas covid-19. Jadi, secara garis besar anggaran untuk penyelenggaraan pilkada ini dibagi menjadi dua bagian besar, yakni untuk pembiayaan seluruh tahapan pilkada oleh penyelenggara dan pengadaan seluruh alat kesehatan untuk memenuhi standar kesehatan (protokol covid-19) mulai dari alat rapid test hingga Alat Pelindung Diri (APD) dll.

Ketiga, penyelenggara pemilihan (KPU, Bawaslu dan DKPP). Tantangan utama bagi penyelenggra pemilihan adalah harus menyesuaikan semua tahapan pilkada dengan new normal alias hidup "berdampingan" dengan covid-19 sambil menjalani aktivitas seperti biasa. Namun, tetap ada batasan-batasannya. Integritas penyelenggara di tengah pandemi covid 
adalah harga mati. Penyelenggara merupakan pilar utama dalam melaksanakan dan menegakkan pilar demokrasi yang berkeadilan. Tantangan penyelenggara dalam situasi tidak normal seperti saat ini tentunya berat dan tidak gampang tetapi juga tidak bisa dijadikan situasi tidak normal ini sebagai alasan untuk tidak profesional dan menjaga integritas.

Keempat, peserta pemilihan. Pasangan calon, partai politik, tim sukses/tim kampanye harus mematuhi semua aturan baik terkait pilkada maupun terkait protokol covid-19. Keberhasilan pilkada tidak semata-mata dibebankan kepada penyelenggara tetapi juga menjadi tanggung jawab peserta pemilihan karena aktor pilkada itu sesungguhnya adalah peserta pemilihan itu sendiri baik dari partai politik maupun dari independen/perseorangan. Perserta pemilihan harus memberikan pendidikan politik yang baik bagi masyarakat. Peserta pemilihan jangan menggunakan situasi pandemi untuk politik uang. Bantuan kemanusiaan berbalut politik uang adalah pengkhianatan terhadap demokrasi.

Kelima, masyarakat (pemilih). Faktor ini sangat menentukan karena salah satu indikator pilkada demokratis dan berkualitas adalah partisipasi pemilih. Oleh karena itu, pemerintah dan penyelenggara pemilu harus memperhatikan dan menjamin sepenuhnya hak konstitusional masyarakat untuk menggunakan haknya. Pengalaman membuktikan bahwa baik pemilu maupun pilkada DPT selalu menjadi masalah klasik. Selain pemerintah dan penyelenggara, masyarakat diharapkan kesadaran politiknya untuk proaktif mengecek namanya apakah sudah terdaftar atau belum baik secara manual maupun secara daring. Begitupun dalam tahapan penyelenggaraan lainnya yang juga krusial, yakni kampanye dan pungut hitung. Tahap ini biasanya dibanjiri dengan berbagai modus politik uang apalagi situasi pandemi saat ini bisa dimanfaatkan untuk memanipulasi bantuan menjadi politik uang. Keenam, gugus tugas. Dalam pemilu maupun pilkada sebelumnya, belum dikenal yang namanya gugus tugas, apalagi gugus tugas covid-19. Gugus ini memang bukan penyelenggara tetapi sangat menentukan apakah pilkada bisa dilanjutkan atau tidak karena bagaimanapun gugus ini bertanggung jawab untuk memastikan kesehatan masyarakat di masa pandemi ini (Ibid).

Instrumen hukum pilkada di tengah pandemi covid-19 tidak begitu memadai bahkan UU Nomor 6 Tahun 2020 tidak mengatur tentang desain pelaksanaan tahapan a la covid-19 terutama tahapantahapan krusial seperti tahapan pencalonan, kampanye dan pungut hitung yang ramah/berdamai dengan covid-19. Oleh karena itu, perlu didesain secara obyektif dalam PKPU sekalipun UU Nomor 6 Tahun 2020 tidak memerintahkan secara organik untuk pengaturan lebih lanjut terkait desain tahapan sesuai protokol covid. Misalnya, tentang verifikasi faktual dengan metode sensus perlu dipertimbangkan matang karena tidak cocok dengan kondisi pandemi. Metode sensus bisa diganti dengan metode sampel dan/atau menggunakan alat komunikasi yang semakin canggih ini, misalnya video call. Selain itu, metode kampanye diatur dalam Pasal 65 UU Nomor 10 Tahun 2016 terutama tentang pertemuan terbatas dan pertemuan tatap muka dan dialog sudah pasti melibatkan banyak orang dan pertemuan langsung dengan pendukungnya. Perlu desain untuk mengikuti protokol covid-19, misalnya melalui media virtual atau pun terpaksa harus tatap muka maka harus disertai pengawasan yang ketat terhadap pelaksanaan kampanye pertemuan langsung tersebut. Perlu kesadaran dari pasangan calon, partai politik, tim kampanye dan masyarakat untuk mematuhi protokol covid19 sehingga kalau di pemilu lalu banyak 
penyelenggara wafat karena kelelahan dan dalam pilkada tahun ini jangan ada penyelenggara, peserta maupun masyakarat wafat karena covid-19. Demokrasi untuk melayani rakyat bukan membunuh rakyat (Ibid).

Tantangan utama dalam pilkada di tengah pandemi covid-19 ini adalah kesadaran menaati protokol covid dan menghindari kerumunan karena bagaimanapun dalam sebuah ajang politik seperti ini mau tidak mau pasti berurusan/berhubungan dengan massa sehingga perlu pengaturan dan penerapan sanksi yang tegas kepada pelanggarnya. Pilkada di masa pandemi bukan sekadar ajang untuk mencari pemimpin tetapi juga menjaga keselamatan rakyat (masyarakat). Perlu adanya kesadaran dari partai politik, peserta pilkada, penyelenggara pemilu, masyarakat dan semua elemen bangsa agar pilkada bukan saja berkualitas tetapi juga pilkada yang sehat dan menggembirakan (Feka, 2020).

Menurut Garuda Wiko terdapat beberapa tantangan yang dihadapi dalam penyelenggaraan pilkada serentak tahun 2020, yakni Pertama, menguatnya politik transaksional; kedua, politisasi dan kampanye terselubung menggunakan program penanganan covid-19; ketiga, gangguan profesionalitas dan integritas penyelenggara pemilu karena profesionalitas dan integritas penyelenggara pemilihan terdistorsi oleh kekhawatiran, kecemasan, dan ketakutan akan tertular covid-19 pada saat bekerja; keempat, aparatur sipil negara (ASN) dan birokrasi daerah yang tidak netral; kelima, pelaksanaan tahapan pilkada kerap kali bermasalah karena disebabkan faktor internal atau eksternal penyelenggara pemilu, misalnya kendala dalam menjaga akurasi dan validitas data pemilih akibat terganggunya pelayanan KTP elektronik di masa pandemi, tingginya pergerakan atau mobilisasi penduduk antar daerah, serta banyaknya pekerja migran yang kembali ke Indonesia; keenam, persoalan kampanye jahat melalui media digital juga penting menjadi perhatian KPU dan Bawaslu, seperti rapat daring, webinar, maupun diskusi jarak jauh berbasis teknologi. Hal ini bisa saja dimanfaatkan oleh oknum untuk semakin menyebarkan kampanye jahat berupa hoaks, informasi bohong, fitnah, maupun ujaran kebencian melalui platform media sosial atau aplikasi pesan personal. Ketujuh, penundaan atau jeda tahapan pilkada ternyata mempertinggi pula biaya politik (political cost) yang harus dikeluarkan para calon, baik untuk merawat konstituen maupun menjaga elektabilitas. Hal ini membutuhkan biaya yang makin besar karena rentang waktunya makin panjang; kedelapan, pada pilkada serentak tahun ini pemilih akan mengalami skeptis pada proses pilkada karena dampak ekonomi dan psikologis yang mereka hadapi pascapandemi covid-19 lebih dominan ketimbang semangat untuk berpartisipasi dan terlibat dalam proses pemilihan, sehingga masyarakat enggan merespon dengan baik proses pelaksanaan pemilihan yang melibatkan mereka, misalnya, verifikasi faktual dukungan calon perseorangan, coklit data pemilih, kampanye, maupun pemungutan suara. Pada akhirnya, bila tidak dikelola dengan baik, hal ini bisa berakibat pada penurunan penggunaan hak pilih di hari pemungutan suara tanggal 9 Desember. Selain itu, di bulan Desember akan ada perayaan natal bagi umat Kristiani. Tradisi pulang kampung untuk merayakan natal bersama keluarga bisa saja membuat pemilih tidak terlalu memedulikan pelaksanaan pilkada; kesembilan, pada masa pandemi covid-19, diharapkan KPU bersinergi dengan para stakeholder untuk menyiapkan manajemen resiko berupa protokol pengelolaan tahapan pilkada yang kompatibel dengan penanganan covid-19 dan memastikan 
tersedianya fasilitas untuk proteksi kesehatan petugas pemilihan, serta kepatuhan pada disiplin protokol kesehatan penanganan covid-19 (https://www.untan.ac.id). Etika penyelenggara pemilu dan urgensi demokrasi pilkada adalah dua hal yang tidak bisa dipisahkan tetapi saling melengkapi. Tanpa etika, demokrasi yang berkeadilan, tidak mungkin terjadi, dan demokrasi tanpa etika adalah sebuah kesia-siaan.

\section{Penutup}

Bahwa peran DKPP untuk menegakkan kode etik penyelenggara pemilu telah dilaksanakan dengan baik dengan menangani pengaduan dan/atau laporan dugaan pelanggaran kode etik oleh penyelenggara pemilu. Namun hal itu tidaklah cukup untuk menciptakan pilkada berkualitas dan bermartabat karena rusaknya demokrasi tidak semata-mata disebabkan oleh kualitas dan tidak berintegritasnya penyelenggara pemilu tetapi disebabkan pula oleh partai politik, peserta pilkada, tim sukses, masyarakat, Aparatur Sipil Negara, Kepala Derah dan Wakil Kepala Daerah dan lain sebagainya. Ironisnya, DKPP tidak menjangkau pihak-pihak tersebut.

Penulis menyarankan agar kewenangan DKPP diperluas pada pilkadapilkada mendatang tidak saja terbatas pada penyelengara pemilu, tetapi jugua keseluruhan sistem yang terkait dengan pemilu yakni menjangkau penyelenggaraan pemilu. Dengan demikian cita-cita untuk menciptakan pilkada atau pemilu bermartabat dapat terwujud.

\section{Daftar Pustaka}

Bruggink, JJ.H. 2011. Refleksi tentang hukum pengertian-pengertian dasar dalam teori hukum, Penerbit PT Citra Aditya Bakti, Bandung.

Feka, Mikhael. 2020. [Opini] Pilkada Berkualitas di Tengah Pandemi Covid-19, rakyatntt.com, 28 Juni.

------, 2020. [Opini] Pilkada di Tengah Pandemi. 2020. Pos Kupang, 21 September.

Huijbers, Theo. 1995. Filsafat Hukum. Yogyakarta: Penerbit Kanisus.

Rengka, Frans J. 2015. Dialog Hukum dan Keadilan. Yogyakarta: Penerbit Genta Press.

Prasetyo, Teguh dan Muhammad. 2019. Kelembagaan Pemilu Untuk Pemilu Bermartabat Suatu Orientasi Teori Keadilan Bermartabat. Bandung: Penerbit Nusa Media.

Prasetyo, Teguh. 2019. Pemilu dan Etika Penyelenggara Pemilu Bermartabat. Bandung: Penerbit Nusa Media.

Laporan Kinerja Dewan Kehormatan Penyelenggara Pemilu Tahun 2020.

Muhammad. 2019. Peradilan Etika Pemilu Penguatan Akuntabilitas Penyelenggara Pemilu. Jakarta: Penerbit Sekretariat DKPP.

Majalah Dial-Etika Integritas, Gaya Hidup Penyelenggara Pemilu Vol.3 N0.1.

https://www.untan.ac.id diunduh pada tanggal 19 September 2020.

https://www.dosenpendidikan.co.id/etikaadalah/ diunduh pada tanggal 24 September 2020. 